\title{
Evaulation \& workup to detect regions of disproportionate anatomy and its subsequent management in patients of snoring and OSA
}

\author{
Kiran Agarwal, Chitra Mehta, M. K. Sen, J.C. Suri \\ Indian J Sleep M ed 2006;1.1, 45-49
}

See end of article for authors affiliations

Address for correspondence:

J. C. Suri, Head of the

Department, Department of

Pulmonary, Critical Care \&

Sleep Medicine, Vardhaman

Mahavir Medical College \&

Safdarjang Hospital, New Delhi

jcsuri@del3.vsnl.net.in

\begin{abstract}
: 50 patients with complaints of snoring with or without symptomatology O SA were selected. The distribution of symptoms was bimodal either in the paediatric age group (mean age 6.4) or in middleaged $\&$ elderly (mean age 43.94). In children adenoid and/or tonsillar enlargement $(72 \%)$ was the commonest cause followed by facial dysmorphism (20\%). In adults, disproportionate upper airway anatomy at multiple levels with or without skeletal malformation was the most important cause e.g. long thick soft palate (62.8\%), long \& oedematous uvula (42.9\%), webbing of pillars with reduced interpillar distance (40\%). All patients underwent clinical and radiological examination in addition to polysomnographic analysis. Children were generally managed surgically and adults received NCPAP mainly. Surgical treatment was less favored in adults due to involvement of multiple sites.
\end{abstract}

\section{Introduction}

0

bstructive sleep apnea is commonest of all sleep-disordered breathing disorders. Snoring, Upper airway resistance syndrome and 0 bstructive sleep apnea syndrome are its various types. Snoring is known to affect $60 \%$ of the adult population and it antedates the development of obstructive events. After long been ignored as a humorous social problem, snoring is now considered a physical sign of upper airway obstruction. The cardio-respiratory disturbance caused by such episodes of airway obstruction is the reason behind theinterest developing towards these long ignored problems.

\section{Aims \& objectives}

1. to evaluate the morphological and structural changes in the upper airway of the patients of snoring and obstructive sleep apnea.

2. to evaluate the various methods available to help in the diagnosis of the severity of the upper airway obstruction.
3. to evaluate various surgical and non-surgical methods availablefor the correction of the soft tissue and skeletal obstruction causing snoring and obstructive sleep apnea.

\section{Materials \& methods}

This study was a prospective study carried out on 50 subjects with complaints of snoring with or without the symptomatology of obstructive sleep apnea. 35 adults and 15 children formed the part of the study.

A detailed history was obtained from the patient and his bed-partner with the help of a structured sleep questionnaire. A thorough clinical examination including a meticulous otorhinolaryngological examination was done. A cephalometric assessment of the upper airway with the help of a plain digital skiagram of the soft tissues of neck in lateral view was also done. This was followed by an upper airway endoscopy and M ueller's manouevre in adults. All were subjected to polysomnography in special sleep laboratory setting. In adults, a blood examination to rule out thyroid hormone and lipid disorders was also carried out. 
46 Evaulation \& workup to detectregions of disproportionate anatomy and its subsequentmanagementin patients of snoring and OSA

The level of obstruction as to oropharynx/ hypopharynx/ oropharynx and hypopharynx was detected with the help of methods and treatment was tailor-made for the patients.

\section{Observations}

The age distribution profilefor the symptomsis bimodal, i.e., children and middle-aged adults aremore commonly affected. The mean age of symptoms in children was 6.4 years and that in adults was 43.9 years. Thetable showing age distribution profile is as below:

Table 1: Age Distribution $(n=50)$

\begin{tabular}{|l|l|l|}
\hline Age Range & Number of patients & Percentage \\
\hline $0-10$ & 12 & 24 \\
\hline $11-20$ & 7 & 14 \\
\hline $21-30$ & 1 & 2 \\
\hline $31-40$ & 8 & 16 \\
\hline $41-50$ & 15 & 30 \\
\hline $51-60$ & 6 & 12 \\
\hline $61-70$ & 1 & 2 \\
\hline
\end{tabular}

$M$ ale preponderance was noted.( 40 males:10 females)

Themorphometric distribution was different in adults and children:

In adults majority were over-weight or obese while in children majority had normal weight and even some were under-weight. The table showing body mass index in the above groups is as follows:

\begin{tabular}{|l|l|}
\hline BMI in Adults (n=35) & \\
\hline Underweight $(<18.5)$ & - \\
\hline H ealthy weight ( 18.5-24.9) & $6(17 \%)$ \\
\hline Over weight ( 25-29.9) & $13(37 \%)$ \\
\hline O besity class I (30-34.9) & $15(43 \%)$ \\
\hline O besity class II (35-39.9) & $1(3 \%)$ \\
\hline O besity class III ( > 40 ) & - \\
\hline BMI in Children ( $\mathbf{n}=15)$ & \\
\hline Underweight $(<18.5)$ & $2(13 \%)-$ \\
\hline H ealthy weight ( $18.5-24.9)$ & $12(80 \%)$ \\
\hline Over weight ( 25-29.9) & $1(7 \%)$ \\
\hline O besity class I (30-34.9) & - \\
\hline O besity class II (35-39.9) & - \\
\hline
\end{tabular}

Indian Journal of Sleep M edicine (IJSM ), Vol. 1, N o. 1, 2006
The cause of upper airway obstruction in children was mainly adeno-tonsillar enlargement and craniofacial anomaly.

The cause of upper airway obstruction in adults was multiple level obstruction with palate and uvula being the most common sites of obstruction. 0 ther causes included grade II tonsils, webbing of tonsillar pillars and enlarged lateral pharyngeal bands.

Table 3: Upper airway examination in adult patients $(n=35)$

\begin{tabular}{|l|l|l|}
\hline & No of patients & Percentage \\
\hline A. PALAT E & & \\
\hline Long \& Thick & 22 & $62.86 \%$ \\
Long & 4 & $11.43 \%$ \\
N ormal & 8 & $22.86 \%$ \\
Thin & 1 & $2.86 \%$ \\
\hline B. TON GUE & 1 & \\
I & 19 & $2.86 \%$ \\
II & $54.29 \%$ \\
III & 15 & $42.86 \%$ \\
\hline C. UVU LA & 15 & \\
O edematous \& long & $82.86 \%$ \\
O edematous & 8 & $22.86 \%$ \\
Long & 2 & $5.71 \%$ \\
(N) & 10 & $28.57 \%$ \\
\hline D. TON SILS & 2 & \\
G rade 0 & 9 & $5.71 \%$ \\
G rade I & 19 & $25.71 \%$ \\
G rade II & $44.29 \%$ \\
G rade III & $11.43 \%$ \\
G rade IV & 16 & $2.86 \%$ \\
\hline E. pillars and \\
interpillar distance & & \\
Webbing with reduced & 14 & $40.00 \%$ \\
interpillar distance & & $45.71 \%$ \\
Webbing & 5 & $14.29 \%$ \\
(N) & 46 \\
\hline
\end{tabular}

$M$ ajority of the patients who presented to us had obstructive sleep apnea syndrome(86\%). Snoring was noted in $8 \%$ and U pper airway resistance was seen in $6 \%$ of the presenting population. 
In adults the results of upper airway endoscopy with Muller's manouevre revealed the level of obstruction to be both simultaneously at oropharynx and hypopharynx more commonly $(48.57 \%)$. The next common site was oropharynx seen in $7(20 \%)$ of the adult patients.

Endocrine disturbances, more commonly hypothyroidism, growth hormone disorders have long been recognized to be the contributing factors to soft tissue obstruction was also noted in our study. 5 adults out of 35 who presented to us were hypothyroid and had significant improvement in their symptoms following its treatment.

Cephlalometric analysis of our patients is shown below:

$34 \%$ had enlarged soft palate and $37 \%$ had enlarged soft palate as well as reduced posterior airway space further confirming upper airway endoscopy findings. $60 \%$ of the patients had hyoid located lower than $80 \mathrm{~mm}$ while others had hyoid at normal position.

Table 4: Cephalometric analysis of our patients

\begin{tabular}{|l|l|l|}
\hline $\begin{array}{l}\text { Soft palate \& } \\
\text { Base of tongue }\end{array}$ & $\begin{array}{l}\text { No of patients } \\
(\mathbf{n = 3 5 )}\end{array}$ & $\begin{array}{l}\text { Percentage } \\
\mathbf{( \% )}\end{array}$ \\
\hline N ormal & 7 & 20 \\
\hline $\begin{array}{l}\text { Increased soft palate } \\
\text { length }(37 \pm 3) \mathrm{mm}\end{array}$ & 12 & 34 \\
\hline $\begin{array}{l}\text { Reduced posterior } \\
\text { airway space }(11 \pm 1) \mathrm{mm}\end{array}$ & 3 & 9 \\
\hline $\begin{array}{l}\text { Increased SPL + } \\
\text { Reduced PAS }\end{array}$ & 13 & 37 \\
\hline H yoid & & 60 \\
\hline Low hyoid position & 21 & 40 \\
\hline N ormal $(15 \pm 3) \mathrm{mm}$. & 14 & \\
\hline
\end{tabular}

Polysomnography was performed in all patients except 2 children who presented with severe respiratory distress and emergency trachestomy had to be performed on them. Polysomnographic analysis co-related well with the clinical findings, i.e, the patients in whom greater degree of upper airway obstruction was suspected had lower minimum $\mathrm{O}_{2}$ saturation and higher mean A pnea$H$ yponea index and poor quality sleep.

The treatment was tailor-made as per the patient:

$>$ In children the primary cause was adenotonsillar hypertrophy hence main mode of treatment was surgical in the form adenoidectomy and/ or tonsillectomy.

$>$ In adults the primary reason was disproportionate upper airway anatomy at multiple levels hence the primary mode of treatment was N CPAP and weight management.

Table 5: Treatment given :

\begin{tabular}{|c|c|c|}
\hline Treatment & $\begin{array}{l}\text { N umber } \\
\text { of patients }\end{array}$ & Percentage \\
\hline $\begin{array}{l}\text { N CPAP with Weight } \\
\text { M anagement }\end{array}$ & 17 & $34 \%$ \\
\hline Adenotonsillectomy & 8 & $16 \%$ \\
\hline Adenoidectomy & 6 & $12 \%$ \\
\hline Weight $M$ anagement & 4 & $8 \%$ \\
\hline $\begin{array}{l}\text { Thyroid hormone } \\
\text { replacement with Weight } \\
\text { M anagement }\end{array}$ & 3 & $6 \%$ \\
\hline $\begin{array}{l}\text { Thyroid hormone } \\
\text { replacement with Weight } \\
\text { Management with N CPAP }\end{array}$ & 1 & $2 \%$ \\
\hline $\begin{array}{l}\text { UPPP with Weight } \\
\text { M anagement }\end{array}$ & 1 & $2 \%$ \\
\hline $\begin{array}{l}\text { UPPP with H yoid } \\
\text { suspension with Weight } \\
\text { M anagement }\end{array}$ & 3 & $6 \%$ \\
\hline $\begin{array}{l}\text { UPPP with thyroid } \\
\text { hormone replacement with } \\
\text { Weight M anagement }\end{array}$ & 1 & $2 \%$ \\
\hline $\begin{array}{l}\text { UPPP with septoplasty with } \\
\text { Weight } M \text { anagement }\end{array}$ & 1 & $2 \%$ \\
\hline Tonsillectomy & 1 & $2 \%$ \\
\hline $\begin{array}{l}\text { Tracheostomy with UPPP } \\
\text { with adenoidectomy and }\end{array}$ & 2 & $4 \%$ \\
\hline \multicolumn{3}{|l|}{ M andibular distraction } \\
\hline Tracheostomy & 1 & $2 \%$ \\
\hline M andibular distraction & 1 & $2 \%$ \\
\hline
\end{tabular}

All the patients were followed up at regular intervals and the objective analysis of improvement was done at 3 months post-treatment. They were asked to refill the 
questionnaires and undergo repeat polysomnography.

\section{Discussion}

O bstructive sleep apnea is gaining new mile-stones, previously regarded as a social annoyance has gained the attention of scientific minds and is being considered seriously and newer methods are being developed for its management. In 1837 Charles Dickens had described the classic Picwickian Syndrome which had a good description of Obstructive Sleep Apnea- obesity, hypersomnolence, etc. After more than a century sleep research was actively pursued by Aserinsky, K leitman \& D ement at the University of C hicago in 1950s. ${ }^{1}$ In 1973 sleep apnea as a syndrome was first described by G uilleminault et al. ${ }^{2}$ They also established a sleep clinic at the Stanford University.

Primary snoring implies loud upper ai rway breathing sounds in sleep, without episodes of apnea or hypoventilation. O bstructive sleep apnea is defined as repetitive episodes of upper airway obstruction that occurs during sleep, usually associated with a reduction in blood oxygen saturation with associated features of daytime sleepiness and snoring.( International Classification of Sleep Disorders).

The site of upper airway obstruction lies in pharynx. Pharynx is a multipurpose tube serving as a passage for respiratory tract and as active propulsive conduit for digestive tract. Its also actively assists in phonation. The compliance of pharyn $x$ greatly assists in swallowing and speaking but makes it susceptible to collapse. Furthermore, the pharyngeal airway is relatively unprotected by any bone or cartilage framework and hence its patency depends greatly on the complex neuromuscular control.

Various soft tissue and skeletal abnormalities of the upper airway can predispose to obstruction. In children, most frequently implicated cause is hyertrophic tonsils and adenoids. ${ }^{2}$ In adults redundant oropharyngeal tissues ( large edematous uvula, long and/ or low hanging soft palate, thick soft palate, large tongue, large tonsils, redundant mucosal folds of lateral pharyngeal wall) and obstructing hypopharyngeal structures( large base of tongue, hypertrophic lingual tonsils, floppy epiglottis with redundant ary-epilglottic folds) are the causes. ${ }^{3}$ 0 bstruction due to skeletal causes include micrognathia, retropositioned mandible, maxillary hypoplasia, abnormal angulation of skull base. ${ }^{4}$ Syndromes associated with O bstructive sleep apnea are D own's Syndrome, Alpert's Syndrome, Treacher Collin's Syndrome, Prader Willi Syndrome. ${ }^{4}$

Snoring and excessive daytime sleepiness are the cardinal manifestations of 0 bstructive sleep apnea. 0 thers symptoms include physically restless sleep, choking, witnessed apneas, dyspnea, fatigue, morning headache, poor concentration, reduced dexterity, depression, personality changes,etc.( American Sleep Disorders Association,1997).

Clinical examination and detailed otorhinolaryngological examination along with upper airway endoscopy helps in assessment of the cause of obstruction. Special studies like Polysomnography, M ultiple Sleep Latency Test, M aintenance of Wakefulness Test help to document thetype and severity of obstructive breathing during sleep.

The various treatment measures available are:

General- improve sleep hygiene, weight management, treatment of hypertension

Specific- Nasal Continuous Positive Airway Pressure(N C PAP), Surgical treatment, 0 ral appliances, $M$ edical treatment.

Improvement of sleep hygiene and weight loss causes complete resolution of airway obstruction and normalization of genioglossus activity after moderate weight loss. ${ }^{5}$

Sullivan et al had first published the study of continuous positive airway pressure (CPAP) for nonsurgical treatment of OSA in $1981 .{ }^{6} \mathrm{~N}$ asal CPAP acts as a pneumatic splint to prevent collapse of the pharyngeal airway and is credited as the "gold standard" for treatment of moderate to severe obstructive sleep apnea syndrome. The effectiveness of CPAP can only be comparable to tracheostomy $(>90 \%)$. It dilates the upper airway without needing to know the level of obstruction. It has a very low risk, is immediately and demonstrably effective and relatively inexpensive, over time. Compliance is the main limiting factor.

Surgery for snoring and OSA available are tracheostomy, adenoidectomy and/or tonsillectomy, uvulopalatopharyngoplasty, maxillomandibular advancement. It is very important to identify the exact site of collapse preoperatively and most adults with disproportionate anatomy require correction at multiple levels. Increased success rates are seen when multiple 
procedures are used that address various sites of obstruction. ${ }^{7}$

In conclusion, the site of upper airway obstruction is at multiple levels. M eticulous clinical and upper airway endoscopic examination along with radiological examination is required to detect the above. Polysomnography helps to assess the severity of obstruction. Multiple modes of treatment suiting individual needs are available. In our study, response to treatment was most commonly and more easily achieved in children and in adults, who used N CPAP. The obstruction and severity of snoring and its potential to lead to OSAS are to be diagnosed and evaluated at the earliest to prevent development of potentially dangerous complications.

\section{Authors' affiliations}

Dr. J. C. Suri, Head of the Department Dr M. K. Sen, Senior Chest Physician

Dr Chitra Mehta, Ex. Resident

Dr. Kiran Agarwal, Sr. Resident, Department of ENT

Department of Pulmonary, Critical Care $\&$ Sleep Medicine, Vardhaman Mahavir Medical College \& Safdarjang Hospital, New Delhi

\section{References}

1. Aserinsky E, Kleitman N: Regular occurring periods of eye motility and concomitant phenomena during sleep,Science 118: 273, 1953

2. Guilleminault $\mathbf{C}$, Eldrige $\mathrm{FL}$, Dement WC: Insomnia with sleep apnea: A new syndrome, Science 181: 856-858, 1973.

3. Fairbanks DNF, Fujita S: Snoring and Obstructive sleep Apnea $2^{\text {nd }}$ Editon 1994 Raven Press Limited New York, 20

4. Sher AE: O bstructive Sleep Apnea Syndrome: a complex disorder of the upper airway. Otolaryngol Clin North Am 23: 593 - 608,1990.

5. Remmers JE, De Groot WJ, Sauerland EK, et al : Pathogenesis of upper airway occlusion during sleep, J Appl Physiol 44: 931-8,1978.

6 Sullivan CE, Issa FG, Berthon-Jones M, Eves L: Reversal of obstructive sleep apnea by continuous positive airway pressure applied through the nares, Lancet 1:862-5, 1981.

7. L $\mathbf{K K}$, Riley R, Powell $\mathrm{N}$,et al: O bstructive sleep apnea surgery patient perspective and polysomnographic results, O tolaryngol Head Neck Surg 123: 572-5,2000. 